\title{
Editorial
}

\section{Eve Teasing- A Social Evil in Bangladesh}

\author{
Ahmad $\mathrm{M}^{1}$, Mollik $\mathrm{MJH}^{2}$
}

The term eve teasing is of Indian origin replacing literary term of sexual harassment. It means making fun of a young girl playfully, unkindly or annoyingly. It usually begins as an attempt by young boys or even adult men to draw attention of a girl with a sly whistle, clapping, singing some top hit cinema songs, taking video by mobile, giving missed call, sending indecent SMS, showing obscene video clips, pressing or touching body parts of opposite sex in crowded place, throwing offensive comments, lingering look to females, giving unwanted proposals etc. The eve teasers include- students, jobless young men, bus conductors, street vendors, rickshaw puller, labours or supervisors/ colleagues at working places etc.

Although women's rights are the subject of a growing public awareness, eve teasing is a burning problem and traditional backdrop in Bangladesh where chastity of a woman is of utter importance. Victims of eve teasing suffer in silence rather than protest against such practice, because it would be socially more demeaning inviting unwanted attention ${ }^{1}$. The probable causes of eve teasing in our country includes- women's subordination, negative attitude towards female population, bad impact of electronic media, lack of proper security, flaws in existing special laws, absence of proportionate punishment etc ${ }^{2}$.

A recent study from Islamic perspective has identified some other points as causative factors of eve teasing which includes curious natural attraction to each other, lack of religious study, unmindful about religion, unfair dress, open sky culture, absence of family education, political patronization, cultural aggression, absence of proper law and order, alcoholism and drug addiction, unemployment, lack of social bondage, irrational use of computers/ mobile, obscene / pornographic cinema and environmental issues ${ }^{3}$.
Parents are always concerned about their daughter's safety, so they look for alternative like early marriage and curtailing education, which hindered normal development of a girl, making her depressed, at the same time increasing suicidal tendency. Both the young girls and their parents suffer from lack of security due to chance of attack from convicted persons or hoodlums.

Bangladesh has a number of laws against sexual harassment/ eve teasing. Bangladesh has identified violence against women as a priority issue since Beijing platform of action (1995). Articles 27, 28, 29 of the Constitution of the People's Republic of Bangladesh entitle women of equal rights and status to those of men. But in real life, discrimination between men and women exists. The penal code of 1860 addressed sexual offence with due importance. Under section 376, offender of rape is punished with a maximum term of rigorous life imprisonment. Under section 354 of penal code, punishment of non penetration sexual assault (outrage modesty) is maximum term of two years imprisonment of either description or with fine or with both. Under section 509, punishment of non contact sexual insult (insult the modesty of a woman) is one year simple imprisonment of either description or with fine or with both ${ }^{4}$.

Dhaka Metropolitan Police ordinance (DMPO-1976), section 76 explains penalty for teasing woman as -Whoever willfully or indecently exposes his person in any street or public place within sight of, and in such manner as may be seen by, any woman, whether from within any house or building or not, or willfully presses or obstructs any woman in a street or public place or insults or annoys any woman by using indecent language or making indecent sounds, gestures, or remarks in any street or public place, shall be punishable with imprisonment for a term which may extend to one year, or with fine which

1. Lt Col Mushtaq Ahmad, MBBS, DFM, MCPS, FRSPH, Associate Professor \& Head, Department of Forensic Medicine \& Toxicology, AFMC, Dhaka Cantonment; 2. Maj Gen Md Jahangir Hossain Mollik, MBBS, MPH, MSLCP (USA), Commandant, AFMC, Dhaka Cantonment. 
may extend to two thousand taka, or with both ${ }^{5}$. Nari O Sishu Nirjaton Domon Ain 2003, section 9(ka) states if a woman is forced to commit suicide as a direct consequence of somebody's willful dishonor /sexual harassment/ assault, then the offender will be liable to a maximum of ten years and minimum five years imprisonment ${ }^{2}$. All these laws needed to be implemented in proper ways.

The article published in this edition of JAFMC on Eve teasing and adolescent depression is a praise worthy cross sectional study. It will contribute a lot to identify the depressive states among victims of eve teasing and suggested solution. Violence against women in Bangladesh is a social evil. Social mobilizations, proper education, maintenance of ethical issues in daily life are suggestive to curve this problem. The situation will become more alarming if concern authority fail to encounter this gender based offence in due time, otherwise it will have long term adverse effect on young females.

\section{References}

1. Khair S. Understanding sexual harassment in Bangladesh: Dynamics of male control and Female Subordination. The Dhaka Univ Studies 1998; 9(1):88.

2. Faruq F. Eve teasing: A Social disaster for women in Bangladesh. Eastern Univ J. 2011; 3(3):40-9.

3. Hoque MA. Eve teasing in Bangladesh: causes and impact on society; a study from Islamic perspective. Int J Social Science 2013;15(1):1-11.

4. Bangladesh Penal Code of 1860. [internet][cited 2015 August 21]. Available at http://www.oecd. org/ site/adboecdanti-corruptioninitiative/46812525.pdf

5. Dhaka Metropolitan Police Ordinance (DMPO1976), [internet] [cited 2015 August 21]. Available at http://bdlaws.minlaw.gov.bd/pdf_part.php?id=511. 